\title{
Organik ve İnorganik Materyallerin İnce Bünyeli Toprağa İlavesi ile Hazırlanan Yetişme Ortamlarının Hidrofiziksel Özellikleri*
}

\author{
Banu KADIOĞLU ${ }^{1 * *(D) \quad M u s t a f a ~ Y . ~ C A N B O L A T ~}{ }^{2}$ (D) \\ ${ }^{1}$ Doğu Anadolu Tarımsal Araştırma Enstitüsü Müdürlüğü, Erzurum, Türkiye \\ ${ }^{2}$ Atatürk Üniversitesi, Ziraat Fakültesi, Toprak Bilimi ve Bitki Besleme Bölümü, Erzurum, Türkiye \\ $\left({ }^{* *}\right.$ Sorumlu yazar e-mail: banu250@ @otmail.com) \\ DOI: 10.17097/ataunizfd.453748
}

Geliş Tarihi (Received Date): 15.08.2018

Kabul Tarihi (Accepted Date): 19.02.2019

\begin{abstract}
ÖZ: Bu araștırma; pomza, perlit gibi inorganik ve torf gibi organik materyallerin, ince bünyeli bir toprağa, farklı oranlarda karıștırılması ile hazırlanan yetişme ortamlarının hidrofiziksel özelliklerini belirlemek amacıyla yürütülmüsştür. Hidrofiziksel özelliklerden nem içeriği, hazırlanan yetişme ortamlarının doygun duruma getirilmesi sonrasında kontrollü koşullarda kurutulması ile doygun hidrolik iletkenlik ise sabit su seviyeli permeametre yöntemi ile tayin edilmiştir. Araştırma sonuçlarına göre, örneklerin doygun durumundan, nem kaybının sonlandırıldığı süreye kadar geçen kuruma sürecindeki ortalama hacimsel nem içeriği değeri, torf: toprak ortamında en yüksek (\%34.1), pomza: toprak ortamında ise en düşük $(\% 22.9)$ bulunmuștur. Pomza ve perlitin toprakla olan $\% 25: \% 75$ karışım oranının diğer ortamlardan daha yüksek su tutma kapasitesine sahip olduğu belirlenmiştir. Denemede üzerinde çalıșlan yetișme ortamlarının doygun hidrolik iletkenlik değerleri, hem materyal (pomza, perlit ve torf) hem de karışım oranları tarafindan önemli seviyede etkilenmiştir. Yapılan çoklu karşılaştırma testi sonucunda, pomza, perlit ve torf'un hidrolik iletkenlik üzerine oluşturduğu etki bakımından materyallerin ve karışım oranlarının birbirinden farklı $(\mathrm{p}<0.05)$ olduğu saptanmıştır. Elde edilen sonuçlara göre, araştırmada kullanılan materyallerin ince bünyeli toprağa ilavesinin yetişme ortamının fiziksel özellikleri üzerinde etkili olacağı, bu durumunda ortamdaki canlı faaliyetleri ile bitki gelişimi üzerine olumlu yönde katkılar să̆layacağı ifade edilebilir.
\end{abstract}

Anahtar Kelimeler: Hidrofiziksel özellikler, Pomza, Perlit, Torf, Yetişme ortamı

\section{Hydrophysical Properties of Growing Media Prepared by Addition of Organic and Inorganic} Materials to Fine Textured Soil

\begin{abstract}
The purpose of this study was to determine the hydrophysical properties of the growing media prepared by mixing different doses of inorganic materials such as pumice and perlite, and organic material such as peat into fine textured soil. Moisture content from hydrophysical properties of growing media was determined by drying saturated samples under controlled conditions and saturated hydraulic conductivity was determined according to the constant water head method. The results indicated that the mean volumetric moisture content of the samples from the saturation state until the end of the moisture loss was the highest in the "peat:soil" media (34.1\%) and the lowest in the "pumice: soil" media (22.9\%). It was also determined that water holding capacity of the mixing media at 25\%:75\% pumice and perlite was higher than these of the other mixing media. Saturated hydraulic conductivity values of the growing media were significantly affected by both material (pumice, perlite and peat) and mixture rates. As a result of the multiple comparison test, it was determined that materials and mixture ratios were different ( $\mathrm{p}$ $<0.05$ ) in terms of the effect of pumice, perlite and peat on hydraulic conductivity. In conclusion it can be stated that the addition of the materials used in this study to a fine textured soil would have effects on physical properties of the growing media and would contribute positively on both living activities and plant development.
\end{abstract}

Keywords: Hydrophysical properties, Peat, Perlite, Pumice, Growing media

"Bu makale, "Pomza perlit ve torf materyallerinin toprakla karıștıılmasından hazırlanan ortamların hidrofiziksel özellikleri ve bu ortamlarda farklı bakterilerle aşılanmış bitkilerin gelişimi” başlıkı doktora tezinden hazırlanmıştır.

\section{GÍRIS}

Doğal kaynaklarımızdan olan toprak ve su bitkisel üretim ortamının temel bileşenlerindendir. Bu kaynakların aşırı ve yanlış kullanılması, ekolojik dengenin bozulmasina ve canlı faaliyetlerinin sürdürülebilirliliğinin kısıtlanmasına neden olabilmektedir. Günümüzdeki öncelikli konulardan biri toprak varlığının korunması diğeride kaliteli ve güvenli gıda üretimidir.

Tarımsal üretimde toprakların sahip olduğu özelliklerin bilinmesinin yanında, verimliliğinin sürdürülebilir olarak arttırılmasına katkı sağlayacak kültürel uygulamalar büyük önem taşır.
Kaliteli bir yetişme ortamı; iyi havalanma ve drenaja, uygun kütle yoğunluğuna, nem karakteristiklerine, reaksiyona, elektriksel iletkenliğe, katyon değişim kapasitesine, dengeli ve optimum besin elementi ile bu elementleri sağlama düzeyine sahip olmalıdır. Yetişme ortamı, iyi drenaj koşullarını sağlaması yanında sulama sıklığını azaltacak özelliklere de sahip olmalıdır. Toprak ortamında bitki gelişimi için ideal koşulları sağlamak amacıyla toprağın fiziksel ve kimyasal özelliklerini düzenlemede farklı organik ve inorganik materyaller kullanılmaktadır. $\mathrm{Bu}$ amaçla pomza, perlit gibi 
inorganik materyallerle torf gibi organik materyaller bitki yetişme ortamlarında kullanılmaktadır.

Pomza, toprağın su tutma özelliğinin geliştirilmesi amaciyla kullanılan bir materyaldir. A ğır bünyeli topraklarda da, fiziksel koşulların iyileştirilebilmesi için toprağa pomza ilavesi önemli bir uygulamadır. Bu materyalin toprağa karıştırılması ile hazırlanan ortamlarda uygun toprak fiziksel koşulları gelişerek, hava ve su dengesinin optimum düzeylere gelmesi sağlanır (Cabrera, 2003; Şahin et al. 2004; Kuşlu vd., 2005; Şahin ve Anapal1, 2006).

Tarımda kullanılan perlit, havalanma ve drenajı geliştirmesi, bitkilere, yarayışlı nemi ve besin elementlerinin elverişliliğini sağlaması, aşırı toprak sıcaklığını önlemede bir yalıtkan olarak görev alması, bitki gelişimi ile ilgili çalışmalarda temiz, kokusuz ve hafif olması nedeniyle farklı avantajlara sahiptir (Bunt, 1988; Varış ve Eminoğlu, 2003; Örs, 2004; Çinkılıç, 2008).

Torf, kimyasal ve fiziksel özellikler bakımından bitki yetişme ortamlarının agronomik karakteristiklerine pozitif katkıda bulunmasından dolayı genellikle organik toprak düzenleyicisi olarak kullanılmaktadır. Uygun fiziksel strüktürü ile bitki kök bölgesinde, su tutma kapasitesi yüksek ve köklerin yeterince havalanmasını sağlayacak bir ortam oluşturan torf, tek başına ve diğer materyallerle karıştırılarak kullanılabilmektedir (Carlile, 2009; Sönmez et al., 2010; Demirkıran ve Cengiz, 2011). Toprağa organik materyal uygulamasının toprakların hacim ağırlığı, porozite ve agregat stabilitesi gibi fiziksel özellikleri üzerine olumlu katkı sağlaması toprağın infiltrasyon hızının artmasina neden olabilmektedir (Hanay, 1991) Hem geleneksel tarımda hem de örtü altı yetiştiriciliğinde bitkisel üretimi artırmak amacıyla toprağın fiziksel özelliklerini geliştirici organik ve inorganik materyallerin toprağa uygulanması ve sağlıklı yetişme ortamlarının hazırlanması önemlidir. $\mathrm{Bu}$ araştırma; pomza, perlit gibi inorganik ve torf gibi organik materyallerin ince bünyeli toprağa farklı oranlarda karıştırılması ile hazırlanan yetişme ortamların hidrofiziksel özelliklerini belirlemek amacıyla yürütülmüştür.

\section{MATERYAL VE METOT}

Araştırmada, Atatürk Üniversitesi Ziraat Fakültesi deneme alanında $39^{\circ} 55^{\prime} 54,1^{\prime}$ ' Kuzey enlemi ve $41^{\circ} 14^{\prime} 14,5^{\prime \prime}$ Doğu boylamı koordinatında, Ap horizonundan alınan Typic Ustorthent sinıfindaki toprağın toprak örneği kullanılmıştır. Araştırma konusu toprak örneği, killi tın bünyeli (kum: \%27, silt: \%32, kil: \%41), organik madde içeriği \%1,17, reaksiyonu $(\mathrm{pH}) 7,5$, agregat stabilitesi \%72, tarla kapasitesi \%38 ve devamlı solma noktası \% 12.5'tir.

Toprak örneğinin özelliklerinin tayininde, tekstür, Bouyoucos hidrometre yöntemi (Demiralay,
1993); organik madde, Smith-Weldon yöntemi (Nelson and Sommers, 1982); toprak reaksiyonu 1:2,5 toprak su süspansiyonunda $(1: 2,5) \mathrm{pH}$ metre ile (Mc Lean, 1982); agregat stabilitesi, rslak eleme yöntemi; toprak nem karakteristikleri, basınç ekstraktörü ile (Demiralay, 1993) tayin edilmiştir.

Araştırmada, inorganik materyal olarak tane büyüklüğü $<4 \mathrm{~mm}$, reaksiyonu 7.1 , kütle yoğunluğu $0.55 \mathrm{~g} / \mathrm{cm}^{3}$, porozitesi $\% 70$, su tutma kapasitesi $\% 20$ olan asit karakterli pomza ile tane büyüklüğü $<2 \mathrm{~mm}$, reaksiyonu 6.5, kütle yoğunluğu $0.13 \mathrm{~g} / \mathrm{cm}^{3}$ 've porozitesi \%66.4 olan perlit kullanılmıştır. Organik materyal olarak reaksiyonu 5.5, kütle yoğunluğu 0.14 $\mathrm{g} / \mathrm{cm}^{3}$ olan torf araştırmada kullanılmıştır.

Çalışmada; pomza, perlit ve torf, toprakla hacimsel olarak 5 farklı oranda (Materyal:Toprak, $\% 100: 0, \% 75: \% 25, \% 50: \% 50, \% 25: \% 75$ ve 0:\%100) karıştırılmış, hazırlanan örnekler, $100 \mathrm{~cm}^{3}$ iç hacime sahip pirinç silindirlere (iç çap: 5 ve yükseklik $5 \mathrm{~cm}$ ) yerleştirilmiş, nem içeriği değişimi (kuruma eğrisi) ve doygun hidrolik iletkenlik denemelerinde kullanılmıştır. Her iki hidrofiziksel özelliğin belirlenmesinde üç ortam ve beş karışım oranı üç tekrarlamalı olarak $(3 \times 5 \times 3=45$ silindir $)$ faktöriyel deneme planına göre araştırılmıştır.

Ortamların kuruma eğrilerinin hazırlanmasında, karışım örneklerinin doldurulduğu silindirler, doygunluğa ulaşıncaya kadar yaklaşık 24 saat süre ile su içerisinde bırakılmıştır. Doygunluk durumu sağlanan örnek silindirleri tartılmış, daha sonra sıcaklığ $50^{\circ} \mathrm{C}$ 'a ayarlı olan kurutma firınına alınmış ve birer gün aralıklarla tartılarak toplamda 150 saat fırında bekletilmiştir. Doygunluktan kuru duruma kadar geçen sürenin 25 saatlik zaman dilimlerine karşılık gelen hacimsel nem içeriği değerleri hesaplanarak, zaman-nem içeriği eğrileri (kuruma eğrisi) hazırlanmıştır (Canbolat, 1999).

Doygun hidrolik iletkenlik tayininde, silindirlere yerleştirilen örnekler doygun duruma gelene kadar 24 saat süre ile su ile doyurulmuş, bu örnekler üzerinde sabit su seviyeli permeametre yöntemi ile hidrolik iletkenlik tayini yapılmıştır (Demiralay, 1993).

Sonuçların İstatistiksel analizlerinde, SPSS 13 paket programı kullanılarak, varyanas analizi ve Duncan çoklu karşılaştırma testi uygulanmıştır (Dowdy and Wearden, 1983).

\section{BULGULAR VE TARTIŞMA}

\section{Yetişme Ortamı Nem İçeriği Değişimi}

Pomza, perlit ve torf materyallerinin toprakla farklı oranlarda karıştırılması ile hazırlanan ve doygun duruma getirilen örnekler üzerinde, doygun durumdan 150. saatin sonuna kadar süren kuruma sürecinin 25 saatlik zaman dilimlerinde belirlenen hacimsel nem içeriği değerlerine ait varyans analizi 
sonuçları Çizelge 1.'de, ortalama hacimsel nem içeriği değerleri Çizelge 2'de verilmiştir.

Varyans analiz sonuçlarına göre, kuruma sürecindeki ortamlar, karışım oranları ve zamanlar hacimsel nem içeriği üzerinde önemli olmuştur. Bu varyasyon kaynakları arasındaki interaksiyonlarında önemli $(\mathrm{P}<0,01)$ bulunmuştur (Çizelge 1.).

Çizelge 1. Yetişme ortamlarının nem içeriği değerlerine ait varyans analizi sonuçları

\begin{tabular}{lcccc}
\hline $\begin{array}{l}\text { Varyans } \\
\text { kaynakları }\end{array}$ & $\begin{array}{c}\text { Serbestlik } \\
\text { derecesi }\end{array}$ & $\begin{array}{c}\text { Kareler } \\
\text { toplamı }\end{array}$ & $\begin{array}{c}\text { Kareler } \\
\text { ortalamas1 }\end{array}$ & $\mathrm{F}$ \\
\hline Ortam (O) & 2 & 8051,9 & 4026,0 & $943,6^{* *}$ \\
Karışım Oranı (KO) & 4 & 2290,7 & 572,7 & $134,2^{* *}$ \\
Zaman (Z) & 6 & 153271,9 & 25545,3 & $5987,4^{* *}$ \\
OxKO & 8 & 8739,0 & 1092,4 & $256,0^{* *}$ \\
OxZ & 12 & 2574,2 & 214,5 & $50,3^{* *}$ \\
KOxZ & 24 & 1819,8 & 75,8 & $17,8^{* *}$ \\
OxKOxZ & 48 & 3205,4 & 66,8 & $15,6^{* *}$ \\
Hata & 210 & 896,0 & 4,3 & \\
\hline
\end{tabular}

**: $\mathrm{P}<0.01$

Çizelge 2'den görüleceği gibi, ortamların karışım oranlarına göre doygun durumdaki hacimsel nem içeriği pomza, perlit ve torfun $\% 100$ olduğu örneklerde sirasiyla \%51.0, \%61.1 ve \%77.3, toprağın \%100 olduğu örnekte ise \%64.1 olarak belirlenmiştir. Doygun durumda en yüksek nem içeriği değeri torf en düşük nem içeriği değeri ise pomza ortaminda olup, bu durumu materyallerin sahip olduğu toplam porozitenin yönlendirdiği ifade edilebilir.

Çizelge 2. Yetişme ortamlarının kuruma sürecinde hacimsel nem içeriği değerleri

\begin{tabular}{|c|c|c|c|c|c|c|c|c|c|}
\hline \multirow{2}{*}{ Ortam } & \multirow{2}{*}{$\begin{array}{c}\text { Karışım } \\
\text { oranı, (\%) }\end{array}$} & \multicolumn{7}{|c|}{ Zaman, h } & \multirow{2}{*}{ Ortalama } \\
\hline & & 0 & 25 & 50 & 75 & 100 & 125 & 150 & \\
\hline \multirow{6}{*}{ Pomza : Toprak } & $100: 0$ & 51.0 & 26.0 & 13.3 & 6.4 & 1.9 & 0.1 & 0.1 & 14.1 \\
\hline & $75: 25$ & 57.6 & 38.4 & 28.4 & 17.1 & 8.1 & 1.5 & 0.5 & 21.7 \\
\hline & $50: 50$ & 61.0 & 43.2 & 35.5 & 25.8 & 15.3 & 4.6 & 0.9 & 26.6 \\
\hline & $25: 75$ & 62.5 & 49.2 & 39.8 & 30.2 & 19.5 & 7.5 & 1.5 & 30.0 \\
\hline & $0: 100$ & 64.1 & 43.8 & 23.5 & 10.9 & 5.6 & 3.5 & 1.7 & 21.9 \\
\hline & Ortalama & $59.2 \mathrm{~g}$ & $40.1 \mathrm{f}$ & $28.1 \mathrm{e}$ & $18.1 \mathrm{~d}$ & $10.1 \mathrm{c}$ & $3.4 \mathrm{~b}$ & 0.9 a & $22.9 \mathrm{~A}$ \\
\hline \multirow{6}{*}{ Perlit : Toprak } & $100: 0$ & $61.1^{\circ}$ & 42.2 & 29.5 & 17.4 & 7.8 & 0.8 & 0.3 & 22.7 \\
\hline & $75: 25$ & 63.6 & 43.3 & 26.4 & 12.0 & 4.8 & 1.2 & 0.6 & 21.7 \\
\hline & $50: 50$ & 62.8 & 46.7 & 32.6 & 19.8 & 10.8 & 3.5 & 1.0 & 25.3 \\
\hline & $25: 75$ & 64.8 & 49.2 & 37.7 & 24.7 & 14.1 & 5.0 & 1.5 & 28.1 \\
\hline & $0: 100$ & 64.1 & 43.8 & 23.5 & 10.9 & 5.6 & 3.5 & 1.7 & 21.9 \\
\hline & Ortalama & $63.3 \mathrm{~g}$ & $45.0 \mathrm{f}$ & 29.9 e & $16.9 \mathrm{~d}$ & $8.6 \mathrm{c}$ & $2.8 \mathrm{~b}$ & $1.0 \mathrm{a}$ & $23.9 \mathrm{~B}$ \\
\hline \multirow{6}{*}{ Torf :Toprak } & $100: 0$ & 77.3 & 67.9 & 59.8 & 48.1 & 34.1 & 14.8 & 1.0 & 43.3 \\
\hline & $75: 25$ & 81.5 & 67.5 & 58.9 & 45.0 & 28.8 & 10.3 & 1.3 & 41.9 \\
\hline & $50: 50$ & 79.2 & 63.1 & 50.6 & 35.7 & 18.7 & 5.5 & 1.4 & 36.3 \\
\hline & $25: 75$ & 71.9 & 53.6 & 33.2 & 17.1 & 8.3 & 3.7 & 1.7 & 27.0 \\
\hline & $0: 100$ & 64.1 & 43.8 & 23.5 & 10.9 & 5.6 & 3.5 & 1.7 & 21.9 \\
\hline & Ortalama & $74.8 \mathrm{~g}$ & $59.2 \mathrm{f}$ & $45.2 \mathrm{e}$ & $31.4 \mathrm{~d}$ & $19.1 \mathrm{c}$ & $7.6 \mathrm{~b}$ & $1.4 \mathrm{a}$ & $34.1 \mathrm{C}$ \\
\hline
\end{tabular}

Ayrı harf ile gösterilen ortalamalar, istatistiksel olarak 0.05 düzeyinde birbirlerinden farklıdır.

Ortamların ortalama hacimsel nem içeriği değerleri birbirinden farklı gruplar içerisinde yer almıştır. En yüksek ortalama hacimsel nem içeriği değeri (\%34.1) torf:toprak karışımında, en düşük ortalama hacimsel nem içeriği değeri (\%22.9) pomza:toprak karışımlarının olduğu ortamda ortaya çıkmıştır (Çizelge 2). 
Çizelge 2'den görüleceği gibi, materyal:toprak karışımlarında materyal içeriğinin azalması, pomza : toprak ile perlit : toprak karışımlarında ortamın nem içeriğinin artmasını sağlamış, ancak torf : toprak karışımında ortamların nem içeriğinde azalma ortaya çıkmıştır. Pomza:toprak karışımında \%100:0, $\% 75: \% 25, \% 50: \% 50$ ve $\% 25: \% 75$ karışım oranlarına sahip ortamlar arasındaki anem içeriğindeki artış, sırasiyla \%53.9, \%22.6 ve \%12.8 olmuştur. Perlit:toprak karışımında \%100:0, \%75:\%25 karışım oranına sahip örnekler arasında bir artış kaydedilmemiş, ancak \%75:\%25, \%50:\%50 ve \%25:\%75 karışım oranlarına sahip örnekler arasında nem içeriğinde sırasıyla \%16.6 ve \%11.1'lik artış olmuştur. Torf: toprak karışımında \%100:0, $\% 75: \% 25, \% 50: \% 50$ ve \%25:\%75 karışım oranlarına sahip ortamlar arasında nem içeriğinde sırasıyla \%3.2, \%13.4 ve \%25,6’lık azalama kaydedilmiştir.

Pomza: toprak karışımında ortalama değerlere göre, kuruma sürecindeki zaman dilimlerine bağlı olarak yapılan değerlendirmede, doygun durumdan ilk 25 saatlik peryodun sonunda hacimsel nem içeriğinde \%32 azalma olduğu, daha sonraki peryotlarda azalan nem içeriğinin sirasıyla \%30, $\% 36, \% 44, \% 66$ ve $\% 73$ olduğu kaydedilmiştir.

Kuruma sürecinde, pomzanın $\% 100$ seviyesi için başlangıç durumuna göre, 75. saate kadar nem içeriğindeki azalmanın yaklaşık $\% 50$ civarlarında gerçekleştiği bu süreden sonra 125 . saate kadar geçen her 25 saatlik peryotta siras ile azalma oranının $\% 70$ ve \% 92.5 civarlarında olduğu belirlenmiştir. Son iki ölçüm (125 ve 150. saatler) arasında ise azalma \%50 olmuştur (Çizelge 2 ve Şekil 1). Oransal olarak nem içeriğindeki en fazla kayıp 100. ile 125. saatler arasında gerçekleşmiştir. Ancak aynı durum sadece toprak örneği içeren ortam için 50 . ve 75 . saatler arasında \%53.7 olarak ortaya çıkmıştır. Bu durum mikro gözeneklerde gelişen nem tansiyonunun ortadan kalktığı süre aralığı olarak değerlendirilmiştir. Pomza:toprak karışımında, $\%$ 25:\%75 oranınına sahip ortamın doygunluk durumu hariç ölçüm yapılan peryotlardaki nem içeriğinin, aynı grup içerisindeki diğer ortamlardan daha yüksek su tutma kapasitesine sahip olduğu belirlenmiştir.

Şahin vd. (2005), yapmış oldukları bir çalışmada toprağa pomza ilavesindeki artışa bağlı olarak düşük tansiyonlarda $(0-0.98 \mathrm{kPa})$ nem içeriğinin de arttığını, yüksek tansiyonlarda (32.36$1471 \mathrm{kPa}$ ) ise karışım oranının artmasına rağmen nem içeriğinde bir azalma ortaya çıktığını kaydetmişlerdir. Diğer bir çalışmada da bitki yetiştirme ortamı olarak değerlendirilen pomza ortamının genel olarak yüksek bir hava kapasitesine sahip olduğu kolay alınabilir su yüzdesinin düşük olduğu ifade edilmiştir (Özgümüş, 1997).

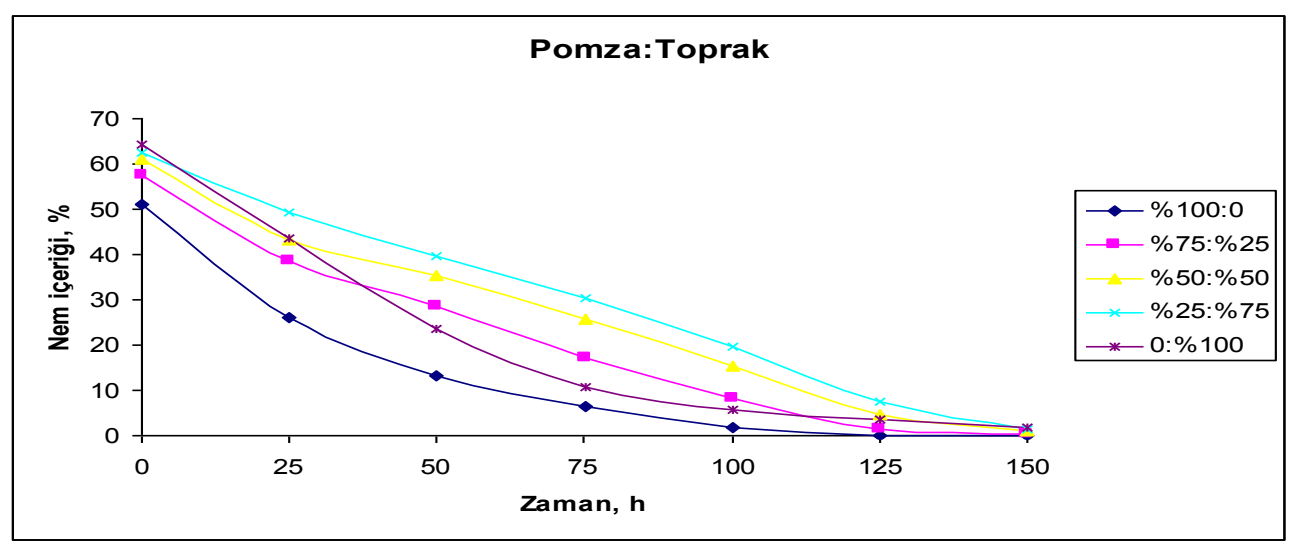

Şekil 1. Pomza ve toprağın farklı karışım oranları için kuruma eğrileri

Perlit: toprak karışımlarında zaman dilimlerine bağlı olarak ortalama değerler arasında yapılan değerlendirmede, ilk 25 saatlik peryodun sonunda nem içeriğindeki azalmanın \%29, sonraki peryotlarda bir önceki ölçüm değerine göre, \%34, \%43, \%49, $\% 68$ ve \%64 oranında nem kaybının gerçekleştiği tespit edilmiştir. Ortamların zamana bağlı olarak değişen nem içerikleri değerlendirildiğinde; doygun durum için en yüksek nem içeriği değeri, perlitin karışımda \%25 seviyesinde bulunduğu ortamda $\% 64.8$ olarak tespit edilmiştir. Bu değerleri perlitin $\% 75, \% 50$ ve $\% 100$ olarak bulunduğu ortamlarda sirasiyla \%62.8, \%63.6 ve \%61.1 olarak takip etmiştir. Doygun durumdan itibaren kontrollü koşullarda kurumaya bırakılan örneklerden perlitin $\% 25$ ve $\% 50$ olarak yer aldığı ortamlar, kuruma sürecinin zaman dilimlerinde en yüksek nem içeriği değerlerine sahip olmuş, bu değerleri perlitin \%100 ve $\% 75$ olarak yer aldığı ortamlar izlemiştir (Çizelge 2. ve Şekil 2.). Bu durum nem içeriğinin yaklaş1k $\% 5$ seviyesine kadar düştüğü 115. saat civarlarına kadar sürmüştür. Ölçüm süreleri arasındaki oransal nem kaybının maksimuma ulaştı̆̆ zaman aralığı, mikro gözeneklerde gelişen nem tansiyonunun ortadan 
kalktığ1 ve daha büyük gözeneklerden suyun boşalabildiği süre olarak değerlendirilmiştir.

Pomza : toprak ortamında olduğu gibi, perlit : toprak ortamındaki \%25:\%75 karışımının aynı grup içerisindeki diğer ortamlardan daha yüksek su tutma kapasitesine sahip olduğu belirlenmiştir.

Perlitin yüksek su depolama kapasitesine sahip olduğu (Jamai et al., 2011), tanelerinin elektriksel yük taşımadığından dolayı ortamdaki su ve besin elementlerinin bitki kökleri tarafından kolaylıkla alınabileceği (Munsuz ve ark., 1982; Verdonck, 1983) bu nedenle yetiştirme ortamlarında perlitin önemli bir materyal olarak kullanılabileceği ifade edilebilir. Perlitin tınlı toprağa karıştırılmasıyla oluşturulan ortamların toplam porozite ve gözenek dağılımları, perlit ortamı ile karşılaştırıldığında, havalanma ve drenajı sağlayan büyük gözeneklerde önemli bir değişikliğin olmadığı, suyun tutulabildiği küçük gözeneklerde ise karışım oranındaki toprak içeriğinin artmasına bağlı olarak önemli bir artışın ortaya çıktığ1 vurgulanmıştır (Örs, 2004). Perlittoprak karışımlarındaki perlit içeriğinin $\% 90$ ve $\% 80$ olması durumunda düşük tansiyonlarda $(\mathrm{pF} 0$ ile $\mathrm{pF}$ 2.52) tutulan su miktarında önemli değişikliğin olmadığ 1 ancak perlitin $\% 70, \% 60$ ve $\% 50$ olarak yer aldığı karışımlarda ise tutulan su miktarında önemli artışların olduğu kaydedilmiştir (Örs, 2004).

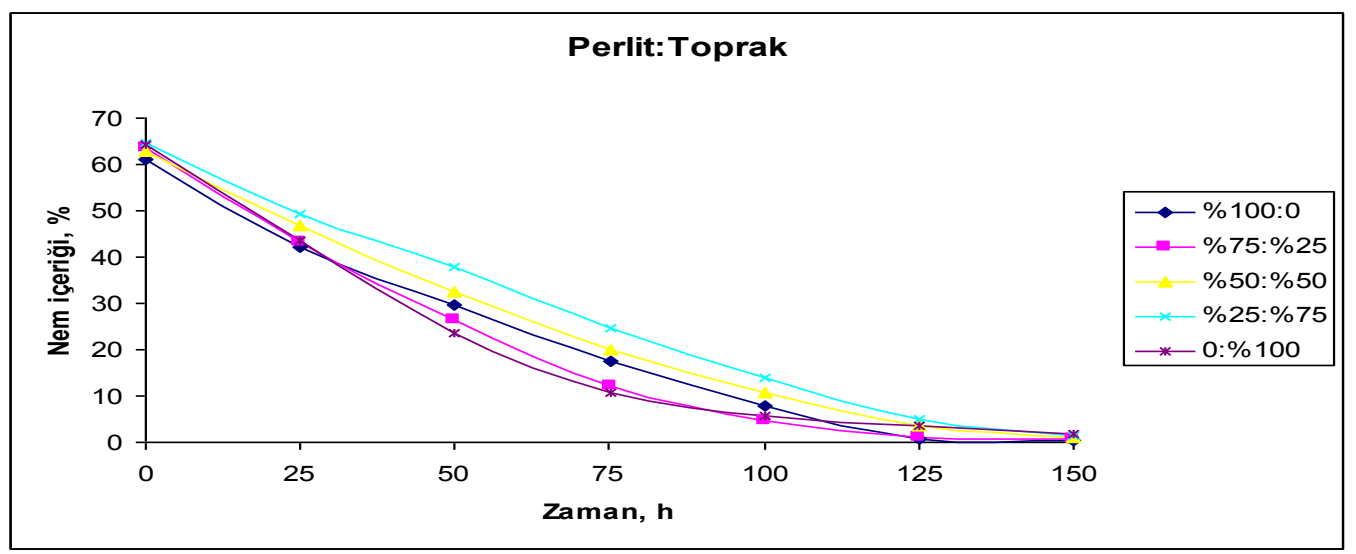

Şekil 2. Perlit ve toprağın farklı karışım oranları için kuruma eğrileri

Torf: toprak karışımında, torf materyalinin artan seviyelerine bağlı olarak nem içeriğinin arttığı tespit edilmiştir. Torf: toprak karışımlarında zaman dilimlerine bağlı olarak ortalama değerler arasında yapılan değerlendirmede, ilk 25 . saatlik peryotta nem içeriğindeki azalmanın $\% 21$, sonraki peryotlarda bir önceki ölçüm değerine göre, $\% 24, \% 31, \% 39, \% 60$ ve $\% 81$ oranında gerçekleştiği tespit edilmiştir. Kuruma sürecinde geçen 150 saatlik süredeki 25 saatlik zaman dilimleri arasındaki nem kayıp oranları pomza ve perlite göre daha düşük oranlarda gerçekleşmiştir (Çizelge 2 ve Şekil 3). Bu duruma hem organik materyalin hemde ortamın gözenek karakterinin neden olduğu ifade edilebilir. Torfun en önemli özelliklerinden biri fazla miktarlarda su absorbe edebilmesi ve bu suyu yapısında tutabilmesidir. Az ayrışmış lifli torfların kuru ağırlıklarının 15-20 katı kadar su tutabildiği, ileri derecede ayrışmış torfların, kuru ağırlıklarının 4-8 katı kadar su tutabildiği, bu tip torfların su tutma kapasitelerinde kuruduktan sonra \%80'e varan bir azalma görüldüğü Özgümüş (1985) tarafından ifade edilmiştir. Organik topraklar kuruduğu zaman meydana gelen büzülme toprağın toplam porozitesini azaltır. $\mathrm{Bu}$ sürecin sonunda gözenek büyüklük dağılımı kapsamında geriye kalan gözeneklerin büyük bir kısmı küçülür ve ancak yüksek tansiyonlarda sadece suyun tutulmasını sağlayabilir. Organik topraklardaki gözenek büyüklük dağılımı kütle yoğunluğu, drene edilebilen gözenekler ve hidrolik iletkenlikle bir ilişki içerisindedir (Michel et al., 2004). Torf ortamında havalanmadan sorumlu makro porların düşük içeriğe sahip olması, ortamda yetiştirilen bitkiler için olumsuz havalanma koşullarını sağlamakta, ayrıca torf ortamında elverişli su miktarının düşük olmasıda bitkiler için olumsuz koşulların ortaya çıkmasına neden olabilmektedir (Verry et al., 2011). Optimum koşullarda bitki gelişimi için ihtiyaç duyulan suyun \%20-30, hava içeriğininde \%20'den az olmamak koşulu bulunmasının önemi farklı araştırmacılar tarafından vurgulanmıştır. (De Boodt and Verdonck, 1972; Şahin et al., 2004) 


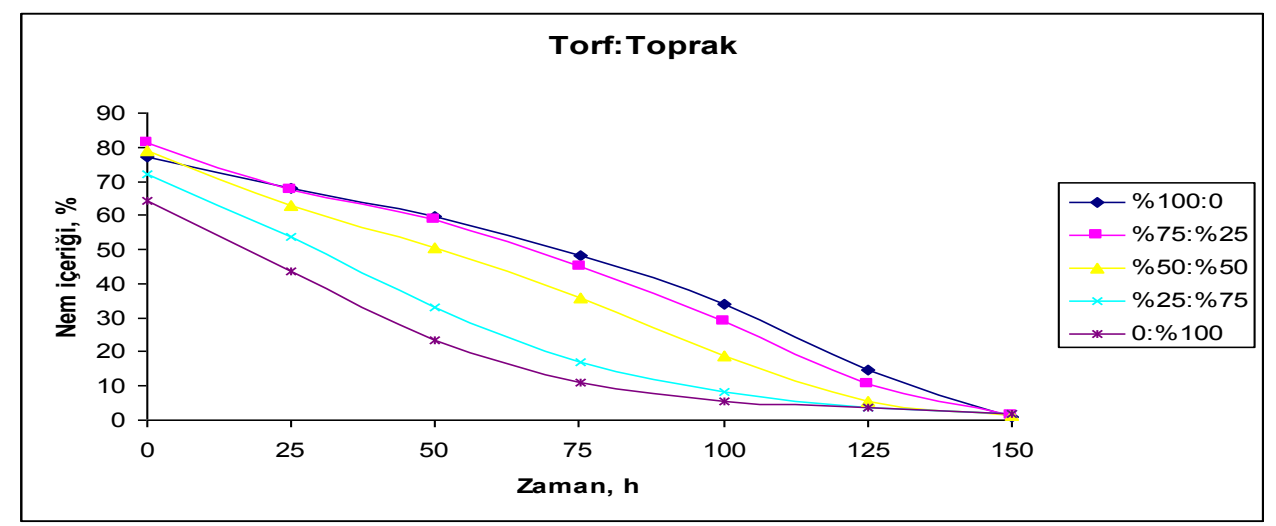

Şekil 3. Torf ve toprağın farklı karışım oranları için kuruma eğrileri

\section{Yetişme Ortamlarının Doygun Hidrolik İletkenliği}

Ortamların doygun hidrolik iletkenlik değerlerine ait varyans analizi sonuçları çizelge 3'de ve ortalama doygun hidrolik iletkenlik değerleri çizelge 4'te verilmiştir. Varyans analiz sonuçlarına göre, hidrolik iletkenlik değerleri bakımından ortamlar ve karışım oranları önemli bulunmuştur (Çizelge 3).

Çizelge 3. Ortamların doygun hidrolik iletkenlik değerlerine ait varyans analizi sonuçları

\begin{tabular}{lcrrr}
\hline Varyasyon kaynakları & $\begin{array}{c}\text { Serbestlik } \\
\text { derecesi }\end{array}$ & $\begin{array}{l}\text { Kareler } \\
\text { toplamı }\end{array}$ & $\begin{array}{c}\text { Kareler } \\
\text { ortalamas }\end{array}$ & \multicolumn{1}{c}{$\mathrm{F}$} \\
\hline Ortam (O) & 2 & 227005 & 113502 & $540,4^{* *}$ \\
Karı̧ım Oranı (KO) & 4 & 1454220 & 363555 & $1730,9^{* *}$ \\
O×KO & 8 & 352340 & 44043 & $209,7^{* *}$ \\
Hata & 45 & 9452 & 210 & \\
Toplam & 59 & 2043017 & & \\
\hline
\end{tabular}

$* *: \mathrm{p}<0,01$

Ortalamalar arasında yapılan çoklu karşlaştırma testi sonucunda, doygun hidrolik iletkenlik bakımından materyallerin ve karışım oranlarının birbirinden farklı $(\mathrm{p}<0,05)$ olduğu tespit

edilmiştir (Çizelge 4.). Doygun hidrolik iletkenlik değeri, pomza: toprak ortamında düşük $(56,4 \mathrm{~cm} / \mathrm{h})$, torf: toprak ortamında ise yüksek $(191,1 \mathrm{~cm} / \mathrm{h})$ bulunmuştur (Çizelge 4).

Çizelge 4. Yetişme ortamlarının doygun hidrolik iletkenlik değerleri

\begin{tabular}{lcccccc}
\hline \multirow{2}{*}{ Ortam } & \multicolumn{6}{c}{ Karışı oranı, \% } \\
\cline { 2 - 6 } & $100: 0$ & $75: 25$ & $50: 50$ & $25: 75$ & $0: 100$ & \multirow{2}{*}{ Ortalama } \\
\hline Pomza: Toprak & 154.5 & 45.3 & 29.0 & 23.9 & 18.3 & $56.4 \mathrm{a}$ \\
Perlit: Toprak & 521.2 & 145.6 & 77.2 & 25.0 & 18.3 & $157.5 \mathrm{~b}$ \\
Torf: Toprak & 636.8 & 171.4 & 90.8 & 38.4 & 18.3 & $191.1 \mathrm{c}$ \\
& $437.5 \mathrm{~d}$ & $120.8 \mathrm{c}$ & $65.7 \mathrm{~b}$ & $29.1 \mathrm{a}$ & $18.3 \mathrm{a}$ & \\
\hline
\end{tabular}

Hazırlanan karışımlarda materyalin bulunma oranına göre, ortamlar arasındaki doygun hidrolik iletkenlik değerlerinin değişim oranları değerlendirilmiştir. Buna göre materyalin $\% 100$ değerinden $\% 75$ değerine düştüğü ortamlarda her üç materyal için doygun hidrolik iletkenlik değerlerinde belirlenen azalma oranı pomza, perlit ve torf için sırasıyla $\% 71, \% 72$ ve $\% 73$ olup, aynı azalma eğilimi göstermişlerdir. Doygun hidrolik iletkenlik değerlerinde azalma eğilimi diğer karışım oranlarına sahip ortamlar arasında da ortaya çıkmış, bu durum, pomza materyalinin ilave edildiği karışımlarda, diğer iki materyal ilaveli karışımlara göre daha düşük bulunmuştur (Çizelge 4.).

Kompost ve perlit gibi organik ve inorganik iki materyalin farklı karışımlarının içeriğinde artan perlit, hidrolik iletkenlik değerleri ile birlikte toplam porozite, yarayışlı su içeriği ve havalanma gözeneklerin artmasında etkili olduğu vurgulanmıştır (El-Hady et al., 2006). Kullanılan materyallerin 
toprakla karışımlarından hazırlanan ortamların doygun hidrolik iletkenlik ve kütle yoğunluğu değerlerinin materyallerin uygulama oranlarına bağlı olarak düşük kütle yoğunluğu ve yüksek doygun hidrolik iletkenlik değerleri ortaya koydukları kaydedilmiştir. Elde edilen sonuçlar Londra (2010)'nın sonuçları ile benzerlik göstermektedir.

\section{SONUÇ}

Araştırmada; pomza, perlit ve torf materyallerinin ince bünyeli toprağa farklı oranlarda karıştırılması ile hazırlanan ortamların altı peryottan oluşan kuruma sürecinde belirlenen hacimsel nem içeriği üzerine yapılan varyans analizinde, materyaller ve karışım oranlarının önemli olduğu belirlenmiştir. Ortamlar ve karışım oranları, ortalama nem içeriği değerlerine göre, birbirlerinden farklı bulunmuştur. Ortamlar dahilinde en yüksek hacimsel nem içeriği değerinin (\%34.1) torf: toprak karışımında, en düşük hacimsel nem içeriği değerinin ise (\%22.9) pomza: toprak karışımlarının olduğu tespit edilmiştir. Ortamların karışım oranlarına göre doygun durumdaki hacimsel nem içeriği pomza, perlit ve torfun $\% 100$ olduğu örneklerde sirasiyla $\% 51.0, \% 61.1$ ve $\% 77.3$, toprağın $\% 100$ olduğu örnekte ise \%64.1 olarak belirlenmiştir. Araştırma sonuçlarına göre, pomza ve perlitin toprakla olan \%25:\%75 karışım oranlarının diğer ortamlardan daha yüksek su tutma kapasitesine sahip olduğu belirlenmiştir.

Materyallerin toprak içerisindeki karışım oranlarının azalmasına bağlı olarak, perlit kuruma sürecinde nem içeriğindeki azalma ile ilişkili olarak diğer iki materyale göre en fazla etkilenen materyal olmuştur. Ortamın toplam porozitesi etkili bir faktör olarak, doygun durumda en yüksek nem içeriğinin torf ortamında, en düşük nem içeriğinin ise pomza ortamında ortaya çıkmasını sağlamıştır.

Ortamların hidrolik iletkenlik değerleri, hem materyal (pomza, perlit ve torf) hem de karışım oranları tarafından önemli seviyede etkilenmiştir. Yapılan çoklu karşılaştırma testi sonucunda, pomza, perlit ve torf'un hidrolik iletkenlik üzerine oluşturduğu etki bakımından materyallerin ve karışım oranlarının birbirinden farklı $(\mathrm{p}<0,05)$ olduğu saptanmıştır. Hidrolik iletkenlik değeri pomzada en düşük torfta ise en yüksek bulunmuştur. Nem içeriği ve hidrolik iletkenlik değerleri üzerine en etkili ortamın torf+toprak ortamı olduğu belirlenmiştir.

Elde edilen sonuçlara göre, araştırmada kullanılan pomza, perlit gibi inorganik ve torf gibi organik materyallerin toprak ortamina ilavesinin toprağın fiziksel özellikleri üzerinde etkili olduğu ve ortam karakterlerini etkileyerek bitki gelişimi üzerinde olumlu katkılar sağlayabileceği kaydedilmiştir.

\section{KAYNAKLAR}

Bunt, A.C., 1988. Media and mixes for containergrown plants. (A manual on the preparation and use of growing media for pot plants). Unwin Hyman. No: 2. London, UK. p: 309.

Cabrera R.I., 2003. Fundamentals of container mediamanagement, Part I, Physical Properties, The State University of New Jersey Agricultural Experiment Station, http://aesop.rutgers.edu/ Floriculture/publicatio ns/physprop.htm (Erişim Tarihi: 15 Kasım 2013).

Canbolat, M.Y., 1999. Farklı agregat büyüklük fraksiyonlarında nem değişimi ve agregat büyüklüğünün bazı nem karakteristiklerine etkisi. Atatürk Üniv. Ziraat Fak. Derg., 30 (1): 73-79.

Carlile, B., 2009. Organic materials for growing media in Europe: current and future scenarios. In: 8th Symposium of the International Scientific Centre of Fertilizer, 8-12 November 2009, Rome (Italy) pp:55-56.

Çinkılıç, H., 2008. Farklı Organik ve İnorganik Ortamlarda Hiyar Fidesi Üretimi. Tekirdağ Ziraat Fak. Derg., 5 (2): 152-158.

DeBoodt, M., Verdonck, O., 1972. The physical properties of the substrates in horticulture. Acta Horticulturae, 26: 37-44.

Demiralay, İ., 1993. Toprak Fiziksel Analizleri. Atatürk Üni. Yayınları No: 143. Erzurum. s: 9095.

Demirkıran, A.R., Cengiz M.Ç., 2011. Değişik Organik Materyaller (Gidya, Alsil, Deniz Yosunu, Hümik asit, yosun ve torf) ile kimyasal gübre uygulamalarının Antep fistığı (Pistacia vera L.) fidanı üzerine etkilerinin incelenmesi. Bingöl Üniv. Fen Bil. Derg., 1 (1): 43-50.

Dowdy, S., Weardin, S., 1983. Statistics for Research. John Wiley and Sons Inc, New York, USA, $537 \mathrm{p}$.

El-Hady, A., Ebtisam, I., Dardiry, E., 2006. Improving hydrophysical properties quality of compost. Journal of Applied Sciences Research. 2 (12): 1137-1141.

Hanay, A. 1991. Organik materyal uygulamasının toprakların înfiltrasyon parametrelerine etkileri üzerine bir araştırma. Atatürk Üniv. Ziraat Fak. Derg., 22 (2): 43-53.

Jamei, M., Guiras, H., Chtourou, Y., Kallel, A., Romero, E., Georgopoulos, I., 2011. Water retention properties of perlite as a material with crushable soft particles. Enginering Geology, 122 (3-4): 261-271.

Kuşlu, Y., Şahin, Ü., Anapalı, Ö., Şahin, S., 2005. Türkiye'nin farklı yörelerindeki pomzaların havalanma porozitesi ve su tutma kapasitesi 
açısından tarımda kullanılabilme olanakları. Türkiye Pomza Sempozyumu, 15-17 Eylül 2005, Isparta, s: 301-306.

Londra, P.A., 2010. Simultaneous determination of water retention curve and unsaturated hydraulic conductivity of substrates using a steady-state laboratory method horstscience. 45 (7): 11061112 .

McLean, E.O., 1982. Soil pH and Lime Requirement. In: Page, A.L., Ed., Methods of Soil Analysis. Part 2. Chemical and Microbiological Properties, American Society of Agronomy, Soil Science Society of America, Madison, pp: 199-224.

Michel, J.C., Naasz, R., Montgermont, N. 2004. A tool for measuring the shrink/swell phenomena of peat growing media by image analysis. Proceedings of the 12th International Peat Congress, 6-11 June 2004, Tampere, Finland II: pp: 321-325.

Munsuz, N., Ataman, Y., Ünver, İ., 1982. Tarımda Yetiştirme Ortamları ve Perlit. Yayın No:10, Etibank Matbaas1, Ankara.

Nelson, D.W., Sommers, L.E., 1982. Organic matter. In: Page, A.L., Miller, R.H., Keeney, D.R. (Eds.), Methods of Soil Analysis. Part 2. Chemical and Microbiological Properties. 2nd ed. ASA SSSA Publisher, Madison, WI, pp. 574-579.

Örs, S., 2004. Perlit ve toprak karışımlarının bazı fiziksel özellikleri ve bu karışımların çilekte vejetatif gelişme üzerine olan etkileri. Atatürk Üniversitesi Fen Bilimleri Enstitüsü Tarımsal Yapılar ve Sulama Anabilim Dalı Yüksek Lisans Tezi, $75 \mathrm{~s}$.

Özgümüş, A., 1985. Bitki yetiştirme ortamı olarak turbanın önemi ve özellikleri. Uludağ Üniv. Ziraat Fak. Derg., 4: 17-24.
Özgümüş, A., 1997. Türkiye'nin değişik yörelerinde yer alan pomzaların bitki yetiştirme ortamı olarak kullanım olanaklarının araştırılması. Uludag Üniv. Proje No: 97/09.

Sönmez, İ., Kaplan M., Demir H., Yılmaz E., 2010. Effects of zeolite on seedling quality and nutrient contents of tomato plant (Solanum lycopersicon cv. Malike F1) grown in different mixtures of growing media. J. of Food, Agric. and Envir., 8 (2): 1162-1165.

Şahin, Ü., Ercişli S, Anapalı Ö, Eşitken A, 2004. Regional distribution and some physicochemical and physical properties of some substrate used in Horticulture in Turkey. Acta. Hort, 648: 177-183.

Şahin, Ü, Örs, S., Ercişli, S., Anapalı, Ö., Eşitken, A., 2005. Effect of pumice amendment on physical soil properties and strawberry plant growth. J. Cent. Eur. Agric., 6 (3): 361-366.

Şahin, U., Anapali, O., 2006. Addition of Pumice Affects Physical Properties of Soil Used for Container Grown Plants. Agriculturae Conspectus Scientificus (ACS), 71(2): 59-63.

Varış, S., Eminoğlu, S. F., 2003. Örtü altı tarımında kullanılan ve kullanılabilecek olan ortamların fiziksel ve kimyasal özellikleri. Hasad Dergisi, 220, 46-57.

Verdonck, O., 1984. New developments in the use of graded perlite in horticultural substrates. Acta Horticulturae, 150: 575-581.

Verry, E.S., Boelter, D.H., Paivanen, J., Nichols, D.S., Malterer, T., Gafni, A., 2011. Physical properties of organic soils. Chapter 5. In: Kolka. R.K.. Sebestyen. S.D. Verry. E.S. Brooks. K. N. eds. Peatland biogeochemistry and watershed hydrology at the Marcell Experimental Forest. Boca Raton., 135-176. 